\title{
The Islamization in Bugis Society during the Darul Islam Era under Kahar Muzakar in I960s
}

\author{
Batari Oja Andini \\ State University of Makassar \\ email:batarioja@gmail.com
}

\begin{abstract}
This paper describes one of the reasons why Islam is so embedded in the identity and the culture of Bugis society. By studying some works of literature about Darul Islam in South Sulawesi and the Bugis pre-Islamic religion, the Islamization process in South Sulawesi was colored by fears, terror, and massacre. It was in Darul Islam Era, under Kahar Muzakar, when Bugis pre-Islamic religion was brutally replaced by Islam since the gerombolan wanted to establish Indonesia Islamic State (NII). This paper also offers a description of Indonesian politics in micro view, the local history of the politics in South Sulawesi.
\end{abstract}

\section{Keywords:}

Islamization, Darul Islam, Bugis, and Kahar Muzakar

\section{Introduction}

Islam is the majority religion in Indonesia. It also becomes the religion which is identical with some ethnic groups in Indonesia. One of the Indonesian ethnic groups which are identical with Islamic culture is Bugis. There is no single Buginese who is not a Muslim. I personally never meet a non-Muslim Buginese. There was one part of the Bugis history in southern Sulawesi that could be the reason why this Islamic identity is constructed in recent Bugis society and how Islam is replaced the Bugis pre-Islamic religion. 
This paper aims to describe the hypothesis of the Bugis history mentioned above by compiling and relating literatures about the Darul Islam movement in South Sulawesi and the Bugis pre-Islamic religion. This paper also describes the relation of the variables, the Darul Islam movement and the Bugis pre-Islamic religion, and how they are related in constructing Islamic identity in recent Bugis society. The period of Darul Islam was the breaking moment in replacing Bugis identity, from Bugis pre-Islamic religion into Islam.

Another purpose of this paper is to remark the Indonesian political history in a micro view. The political history in eastern Indonesia, or in this case southern Sulawesi, is as dynamic as the national history of Indonesia that most of scholars refer to Javanese history as the center of the Indonesian political history.

\section{Bugis Pre-Islamic Religion}

Tome Pires, an apothecary who had spent three years surveying Islam in Indonesian/Malayan archipelago, said that Islam was such a foreign belief in Indonesia in 1512-1515 (Ricklefs 2001, 8-10). Although most kings in Sumatra were Muslims, there were several non-Islamic kingdoms in Sumatra. In the same period, Central Java and East Java were claimed as the center of Hindu-Buddhist civilization in the archipelago. Pires also reports that Brunei in Kalimantan (Borneo) had a king who became a Muslim although the rest of Kalimantan Island had not yet been familiar with Islamic tradition. A similar case was found in South Sulawesi. When Pires was surveying Islam in Indonesia, Bugis and Makassar in South Sulawesi had not possibly recognized Islam yet.

Before the people in southern Sulawesi converted into Islam, there were various belief systems there. According to Lathief (2008, 8-9) the Bugis society had already converted to some particular beliefs, called as Attoriolong, which literally means "the guidance from the people in the 
past" or "the order from the ancestors". It is the heritage of the Bugis ancient kingdom, La Galigo, which history cannot prove whether it is a real kingdom or a sheer myth. The essence of the Bugis ancient religion is the conception of the supreme-spirit, called as ToPalanroe, "one who create"; "a creator". Besides, they also recognized some names of deities and practiced some features of ritual. The typical worshipping system of the Bugis ancient religion is that most of them are offerring activities.

Furthermore, the way Bugis people converted to Islam was different from how Javanese did it. Javanese tended to syncretize Islam with Javanese Hindu tradition; they called it as Islam Kejawen or Javanestic Islam; so they could embrace Islam and practiced their Javanese pre-Islamic tradition at the same time. Bugis people were more sensitive in combining Islam and their tradition to prevent syirik or shirk the deification or worship of anyone or anything other than Allah. Even though Attoriolong worships one creator called ToPalanroe, the worship tradition is different with Islamic tradition. Thus, it is considered as syirik.

One of the syirik practices done in Bugis ancient traditions is the existence of Bissu. Bissu are Bugis priests of Attoriolong who are believed as genderless, besides other four genders namely: male, female, calabai (male acts like women), and calalai (female acts like male). Bissu are commonly transvestite men or high rank of noble women (Lathief 2008, 1-3). The word 'bissu' comes from Bugis language, mabessi, which means clean. They are called as bissu since they are holy, not dirty, have no breast, and no menstruation. Bissu are basically calabai, transvestite men, but calabai are not always bissu.

Although both bissu and calabai dress like women in their daily life and wear Bugis princess' clothes in the ritual, bissu have higher noble status than calabai. In ancient times, calabai were often bullied by people while bissu were respected and honored. Bissu are believed to have miracle and ability to communicate with the spirits. Therefore, they play the most 
important role in the kingdom ritual. Beside their recognized function in Bugis tradition, Bissu are priests who behave in a more classic and noble manner in compared with calabai, who usually dress vulgarly. Calabai usually act aggressively while bissu act elegantly. Bissu are noble or malebbi in Bugis language.

As the spreading of Islam increases rapidly, it significantly affects the previous Bugis tradition of bissu. According to the statistical data in one of the districts in South Sulawesi named Sigeri Mandale, a place where the bissu exist, 100 percent of the total population has embraced Islam (Lathief 2008, 91-95). The people are considered as good Muslims; meaning discipline in practicing the orders of Islam and manifesting the teachings in their daily behaviors (Trofimova 2017; Kovalskaya 2017; Elbasani \& Puto 2017). It has been proved by the existence of a big mosque in the district town. The mosque is always filled with Muslim people in the prayer time, especially in Friday prayer.

According to the Muslims in Sigeri, the whole doctrine of bissu is contradicted with the Islamic teaching. Thus, even though several bissu live in Sigeri, the tradition has faded away and replaced with Islam and the ambition of modernization. The most challenging task for bissu community is to adapt to the dynamic political atmosphere of the nation state or religion. The concrete point of this is the leadership and the regenerating for the continuity of the existence of bissu. Living among the Islamic society leads the bissu to embrace Islam. They are legally Islam in their National Identity Card. Moreover, their leader, Sanro Barlia or Puang Matowa, went to Macca to do Hajj pilgrimage. It is to prove that they are true Muslims. By doing these Islamic religious activities, they hope that they are still allowed to practice their dances and rituals there (Abdugafurov \& Moran 2016; Rudenko et al. 2016; Akaev \& Soltamuradov 2016). 


\section{The Era of Darul Islam/Tentara Islam Indonesia (DI/TII)}

The most estimated menace for the Indonesian Military was the menace from the right party, the Extremist Islam, Darul Islam, and the menace from the left party, the Communist Party, PKI (Partai Komunis Indonesia, Indonesian Communist Party) (McGregor 2008, 314). The military perception of these threats refers to the historical aggression that had been conducted by the both parties. The most dramatic aggression from the communist party was the rebellion in Madiun 1948. Meanwhile, the dramatic movement from the right party was Darul Islam. Both actions were intended to fight against the Indonesian constitution.

According to the Indonesian government, Darul Islam was considered as a brutal movement (Parolin 2016; Janson 2016; Jensen 2016; Kloos 2016). In a film entitled Mereka Kembali produced by the Waspada Purbawisesa Museum, Darul Islam was described as the paramilitary with no value of religiosity at all (McGregor 2008, 332). They were called as terrorists who brutally killed innocent people. The head of the museum claims that the purpose of the movie production is not to marginalize one particular religion. It was only a sheer show to give education to the new generation about the cruelty of Darul Islam (McGregor 2008, 341).

In the middle of revolution, there was a riot in Madiun on 1948 (Hatley in Lindsay \& Liem 2011, 9-10). It destroyed the image of the royal young Indonesian who fought the Dutch with sharp bamboos in their hands. On August 1949, only four months before the legal handover sovereignty to Indonesian Government, the Darul Islam movement proclaimed the independent of Indonesia Islamic State (Negara Islam Indonesia or NII). The based camp of this movement was in West Java. On the beginning of 1950s, the rebellion movement of Darul Islam became more local. On April 1950, the separatist movement in Maluku declared Republic of Southern Molucas (Republic Maluku Selatan or RMS). Then on September 1953, three years later, there was a chaos in Aceh caused by a 
similar type of local separatist movement. On the same year, the leader of the separatist movement in South Sulawesi, Kahar Muzakar, claimed that his movement was related with Darul Islam movement. Indeed, Kahar Muzakar's movement had already run since 1951.

There was an increasing awareness of political affiliation after the declaration of Political Manifesto by President Soekarno in 1959. In South Sulawesi, the member of the rebellion movement of Darul Islam, Kahar Muzakar, was called gerombolan or gangster. They were labeled as a dangerous enemy for the Indonesian government and the whole nation as well. Thus, protecting the member of the gerombolan was a crime that could cause legal punishment.

Although, they were haunted by the Indonesian army in their guerilla, the gerombolan of Darul Islam was close to many noble and land lords in South Sulawesi. Most of the land lords joined the gerombolan since they did not want their land to be dominated by the country. They demanded a privilege to be as powerful as before, as the noble peers and land lords, although Indonesia had been established as a country. The land lords contributed significant supports to the gerombolan of Darul Islam under Kahar Muzakar. On the other hand, the government spread a discourse stating Darul Islam as an illegal movement that caused disadvantages for the local people in South Sulawesi since they fight for land lords' interest rather than local farmers' interest.

The establishment of Darul Islam was merely a political issue. It was a response for the Renville counsel, which was led by Amir Sjarifoeddin in 1948 (Suryanegara 2010, 328). Indonesian government planned to stabilize the institution of Indonesian Military Army (Suryanto 2011). The plan was responded anxiously by local paramilitaries that had fought against the Dutch for the Indonesian independence. They expected that they were required as Indonesian army and become the member of Indonesian Army Institution (APRI). However, most of paramilitaries did not fulfill the 
standards to become Indonesian National Army. Kahar Muzakar as one of the commanders of the paramilitary from South Sulawesi established his own army. Unfortunately, he established the army in the form of rebellious movement. He was inspired by the similar type of movement established by Kartosuwirjo, who declared Indonesian Islamic State.

Kartosuwirjo was a leader of Darul Islam in West Java. He claimed that Indonesian government was failed in making fair decision on their pretension. Meanwhile, Darul Islam was only an ally without any shared idea for Kahar Muzakar and his troops. He braided cooperation with other rebellious movements in Indonesia for the sake of maintaining the sustainability and increasing the power of his own movement in South Sulawesi. He established his own state in South Sulawesi, called RPII, which referred to Islamic law as their constitution.

\section{The Toba Operation}

Regarding Bugis Pre-islamic religion, gerombolan Darul Islam under Kahar Muzakar claimed that bissu tradition was not along with Islamic teaching about the One and Only Almighty God (Lathief 2008, 79-82). The tradition was a form of idol worshiping besides worshiping Allah. It was considered as syirik, the biggest unforgiving sin in Islam. Therefore, the ritual activities in bissu tradition, such as their instruments and the practitioners, were eradicated. Hundreds of the ritual instruments were burnt or drowned in the sea. Many sanro, the Bugis shaman, and bissu were killed or induced to be men and to work hard as men.

At that time, local people were afraid of the gerombolan, as well as of the Indonesian army. Indonesian army conducted similar deed to the local people. They burnt all rice fields so there were no food left for the gerombolan. On the other hand, the gerombolan did not only ask for food but also kill anyone who practiced the ancient bissu ritual or worshipped other than Allah in Islamic ways. 
The crisis of the bissu tradition was continued when the Old Order era was replaced by the New Order era under Soeharto in 1965. The chaos pointed the ritual of the ancient tradition. Arajang, the most sacred object for bissu community, the hierophany, was almost destroyed by paramilitary. A bissu and whoever believed in the sacredness of the arajang was labeled as communist or a member of Partai Komunis Indonesia (PKI). They were labeled as atheists, people who have no religion, syirik people, and animists. Thus, anyone worshipped the arajang was considered as a true sinner of Islam.

A bissu who was caught by the gerombolan would be killed or must change the identity into a real man and be a Muslim. Then, there was a rumor in the society telling that whoever met a bissu would be unfortunate for 40 days and 40 nights. The good deeds and amal done by them during the 40 days would not be accepted by Allah. Therefore, bissu and transvestite people in South Sulawesi had to be expelled as far as possible that no one would even see them. A sanro and a bissu that were used to be respected in the society then became an object of bullying.

That action of purifying Islamic doctrine was called Toba'Operation or Operasi Taubat. This operation was very intense in 1966. At that time, the ancient ritual was forbidden although it is no longer applied in the society nowadays. Some Bugis people secretly believed and practiced their ancient religion although they were forced to be Islam. They must act as if they supported the Toba' Operation. Thus, no one would care of the existence of Bugis pre-Islamic religion even if they did they had to pretend that they did not.

On the other hand, Bugis people still believed that if the harvest was not satisfying; it was because they did not conduct rituals for the Deities. Thus, some local farmers tried to protect the last bissu who was still alive. This Toba' operation was one of the settings that constructed the Islamization in South Sulawesi. 


\section{Conclusion}

The rebellious movement of the gerombolan Darul Islam of Kahar Muzakar in South Sulawesi has played an important role in the cultural system of the local people's belief or religion. The breaking moment was crucial in shifting the local people's belief from the animism into the modern religion, Islam. Therefore, Islam becomes a religion which is identical with the Bugis identity. The Bugis society was concerned with the political situation at that time. Thus, it had an impact to the people's security from many military aggressions and riots. It can be concluded that the successful spreading of Islam in South Sulawesi has been coloured by fears and necessity of local people. 


\section{References}

Abdugafurov, R., Moran, B. 2016. Islamic Law and Elder Care in the Central Asian Edgen System. Journal of Law and Religion 31 (2), pp. 197-211.

Akaev, V., Soltamuradov, M. 2016. Islam: Local Traditions and Innovations in the Context of Russia. Central Asia and the Caucasus 17 (1), pp. 77-84.

Elbasani, A., Puto, A. 2017. Albanian-Style Laicite: A Model for a MultiReligious European Home? Journal of Balkan and Near Eastern Studies 19 (1), pp. 53-69.

Janson, M. 2016. 'How, for God's Sake, Can I Be A Good Muslim?': Gambian Youth in Search of A Moral Lifestyle. Ethnography 17 (7), pp. 22-46

Jensen, S.V. 2016. Institutional Governance of Minority Religious Practices: Insights from A Study of Muslim Practices in Danish Schools. Journal of Ethnic and Migration Studies 42 (3), pp. 418-436.

Kloos, D. 2016. From Acting to Being: Expressions of Religious Individuality in Aceh, ca. 1600-1900. Itinerario 39 (3), pp. 437-461.

Kovalskaya, K. 2017. Nationalism and Religion in the Discourse of Russia's 'Critical Experts of Islam'. Islam and Christian-Muslim Relations 28 (2), pp. 141-161.

Lathief, H. 2008. Bissu:Tradisi Tranvestites Shammans Bugis. Jakarta: Desantara. Latheif, H. 2008. Maggiri: Tari Ekstase Bugis. Makassar: Makassar: Padat Daya.

Lindsay, J \& M.H.T. Liem. 2011. Abli Waris Budaya Dunia: Menjadi Indonesia 1950-1965. Denpasar: Pustaka Larasan.

McGregor, K.E. 2008. Ketika Sejarah Berseragam: Membongkear Ideologi Militer Dalam Menyusun Sejarah Indonesia. Yogyakarta: Syarikat.

Parolin, G.P. 2016. Political Islam in the Mediterranean: Citizenship, Religion, and Constitution. Quaderni di Diritto e Politica Ecclesiastica 19 (1), pp. 167-182.

Rudenko, A., Kotlyarova, V., Polozhenkova, E., Mogilevskaya, G., Sysoeva, O. 2016. Religious Tolerance as a Factor of Spiritual Security in the South of Russia. Central Asia and the Caucasus 17 (2), pp. 37-46. 
Ricklefs, M.C. 2001. History of Modern Indonesia since c.1200 Third Edition. United Kingdom: Palgrave.

Suryanegara, A.M. 2010. Api Sejarah: Buku Yang Akan Menuntaskan Kepenasaran Anda Akan Kebenaran Sejarah Indonesia. Bandung: Salamadani Pustaka Semesta.

Suryanto, E. S. 2011. Peranan Kahar Murakkar Dalam Pemberontakan DI/TII Di Sulawesi Selatan. Lampung: FKIP Universitas Lampung.

Trofimova, K. 2017. Transforming Islam among Roma Communities in the Balkans: A Case of Popular Religiousity. Nationalities Papers 45 (4), pp. 598-612. 
DINIKA, Volume 2, Number I, January - April 2017 